\title{
Okul Müdürlerinin Denetiminin Öğretmenlerin Mesleki Gelişimine Etkisi
}

\section{The Effect Of School Principals' Supervision On Professional Development Of Teachers}

\author{
Serdar KOÇAK ${ }^{1}$, Salih Paşa MEMişOĞLU²
}

\section{Öz}

Araştırmanın amacl; öğretmenlerin görüşlerine göre okul müdürlerinin denetim yeterliliğini ve denetimin öğretmenlerin mesleki gelişimlerine etkisini ortaya koymak ve denetim sistemine yönelik öneriler geliştirilmesidir. Nitel bir araştırma olan bu çalışma olgusal modeldedir. Veriler nitel araştırma tekniklerinden olan yarı yapılandırılmış görüşme tekniği kullanılarak elde edilmiş olup verilerin çözümlenmesinde betimsel analiz tekniğinden yararlanılmıştır. Araştırmanın çalışma grubu ilkokul, ortaokul ve liselerde görevli 30 öğretmenden oluşmaktadır. Araştırma sonuçlarına göre öğretmenlerin denetim kavramına olan görüşlerinin ağırlıklı olarak bir kontrol aracı olarak görüldüğü, okul müdürlerinin büyük çoğunluğunun denetimde yeterli olmadığı, okul müdürlerinin denetimlerinde öğretmenlerin çoğunun olumsuz bir durum yaşamadığı, az sayıda öğretmen denetimin mesleki gelişimlerine etki ettiğini, çoğunluğun ise okul müdürünün yaptığı denetimin mesleki gelişime hiçbir katkısının olmadığını, denetim sisteminin tek bir kişiye bırakılmadan alanında uzman kişilerinde olduğu okul müdürü vb paydaşlarında görüşlerinin alındığı süreç odaklı, yapıcı ve geliştirici olması gerektiğine yönelik görüş belirtmişlerdir.

Anahtar Kelimeler: Okul müdürleri, denetim, mesleki gelişim, öğretmen görüşleri

\section{Abstract}

The aim of the research; according to teachers' opinions, it is aimed to reveal the supervisory competence of school principals and the effect of supervision on the professional development of teachers and to develop suggestions for the supervision system. This study, which is a qualitative research, is a phenomenon model.The data were obtained by using semi structured interview technique which is one of the qualitative research techniques and descriptive analysis technique was used to analyzethe data. The study group consists of 30 teachers working in primary, secondary and high schools.According to the results of the research, it was observed that theteachers' views on the concept of control were seen as a control tool, the majority of the school principals were not sufficient in the audit, most of the teachers did not experience a negative situation in the inspections of school principals, a small number of teachers in fluenced the Professional development of the supervision, The majority of the teachers stated that the supervision made by the school principal has no contributi on to the Professional development and the inspection should not be left to a single person. Experts, school principals and so on. The views of the stakeholders about the teacher should be taken and the inspection should be constructive and developer based on the process.

Keywords: School principals, supervision, professional development, teacher opinions

\footnotetext{
${ }^{1}$ MEB, Öğretmen, Bolu, Türkiye; https://orcid.org/0000-0003-0806-3690

${ }^{2}$ Bolu Abant İzzet Baysal Üniversitesi, Eğitim Bilimleri Fakültesi, Bolu, Türkiye; https://orcid.org/0000-0002-8258-3822

Atıf / Citation: Koçak, S., \& Memişoğlu, S. P. (2020). Okul müdürlerinin denetiminin öğretmenlerin mesleki gelişimine etkisi. Kastamonu Education Journal, 28(2), 806-819. doi:10.24106/kefdergi.697229
} 


\section{Extended Abstract}

Aim and importance: When we look at today, quality in education in the world countries is one of the most important problems. The quality of the teacher is also the main component of the quality of education. Obviously, the quality in education is first possible with the teacher being qualified.Other countries and turkey is a continuing quest to make qualified teachers Professional development is the renewal and expanding learning of the teachers in their profession. Changes and developments in the world are increasing the importance of professional development (Özer, 2008, s. 195) It is no longer a preference to contribute to the development and change of the teacher in the job, but it becomes a necessity for the role of the teacher in the information age. The importance of today's necessity is an indisputable fact. The point that needs to be discussed is how the inservice training and staff development program envisaged for the continuous development of the teacher should be and how the audit should function in this respect (Aydın, 2014, p. 167). Therefore, it has been deemed necessary to investigate the impact of supervision on the professional development of teachers on a scientific basis. According to the teachers' opinions, it was aimed to determine the supervisory competence of school principals and the effect of supervision on the professional development of teachers and to develop suggestions for the control system.

Method: In this study, phenomenology model, which is one of the qualitative research types, was used. The study group consisted of 10 primary school, 13 secondary school and 7 high school teachers who work in primary, secondary and high school public schools in Bolu city center in 2018-2019 academic year. According to gender of the study group, 17 female and 13 male, according to graduation status, 23 people with bachelor's degree and 7 of them master's degree.According to the field variable; classroom teacher 7 people, branch teacher 23 people, according to the working year variable; 3 persons with 5 years, 8 persons with 6-10 years, 11 persons with 11-15 years, 4 persons with 16-20 years, 2 persons with 21-25 years, 2 persons with more than 25 years.

In this study, semi-structured interview form was used to determine the opinions of teachers. While the data collection tool was being created, a literature review was conducted on the subject of research. In addition, interviews were made with persons who were subject area experts and their suggestions were used. The pre-study was conducted on 5 teachers except the participant group.As a result of the application, it was seen that the questions in the form were understood correctly by the participants according to the research purpose. The following questions were asked to the participants in the data collection tool; what does the concept of control mean, what are the factors affecting the teacher in the course supervisor of the school principal, whether the school principal contributes to the professional development of teachers in the course supervision and who asked how the audit should be carried out.

In data analysis, four stages were followed: coding of data, identifying themes in coded data, arranging codes and themes, identifying and interpreting the findings (Yıldırım and Şimşek, 2011).In the analysis of the views of the participants, groupings were made according to the similarity of the expressions. Teachers $(0 \ddot{1} 1,0 \ddot{2})$ are given codes in their analyzes. In addition, for the validity and reliability of the research, the categories were determined within the theoretical framework.In the process of analyzing the data, it is tried to increase the validity and reliability in this way by the two researchers in making the coding and determining the categories separately.

Discussion and conclusion: The results of the research were examined in order; the most majority of teachers' views on the concept of control are seen as a control mechanism. It is concluded that some of the teachers expressed the control as evaluation, observation, examination, follow-up, research and investigation status. When the results of the research about the school supervisors' adequacy of the course supervision are examined, the majority of the teachers do not see the school principal as adequate. The reasons for not seeing as sufficient are lack of knowledge, branch differences, lack of knowledge and equipment, conducting the audit only as a formality task, only examining the classroom management, not having a constructive and positive critical point of view in the audit, were achieved the results. It was concluded that the majority of the teachers did not experience a negative situation under the supervision of the school principal, while some of them experienced a negative situation.

When the results of school principals' supervision effect on the professional development of teachers were examined, the majority of the participants stated that school principals did not make a significant contribution to the professional development of the school principals' supervision and very few have stated that they have a positive effect on their professional development. The teachers who stated that the audit did not contribute to the professional development, as reason for this stated that school principals and teachers had different branches, that the school administrators were not a good teacher, and that the concept of supervision was the only document control.

Based on the results obtained from this study, the following recommendations were introduced; The emphasis should be on professional guidance in auditing, not an error-seeker, but an error-reducing process should be followed, managers should be treated very precisely, The principal of the school should be a good leader in the field of education and training. People who have received a master's degree in education management should be chosen as school principals. School administrators should be trained in the field of supervision and guidance by experts. The control system should be based on the process. It is recommended to develop a school manager, an expert auditor in the field, community teachers and a system in which student success is considered. 


\section{Giriş}

Her alanda gelişimin ve değişimin hızlı bir şekilde yaşandığı 21. Yüzyılda, diğer alanlarda olduğu gibi eğitim alanında da sürekli bir devinim ve değişme görülmektedir. Yaşamın toplumsal ve siyasal yönlerinde meydana gelen gelişim ve değişim süreci, eğitim alanında da değişmeye ve yeniliğe neden olmaktadır. Eğitim yaşam için hazırık olduğu düşünüldüğünde bu durum kaçınılmazdır. Toplumsal ekonomik ve siyasal yaşamda görülen her temel değişmenin eğitim alanına da yansıması, eğitimle diğer toplumsal kurumlar arasında yakın ilişkinin doğal bir sonucudur. Yaşamın değişen yönlerine göre eğitimin de kendisini yenilemesi kaçınılmazdır. Çünkü eğitim ancak o zaman döneminin eğitimi, çağdaş bir eğitim niteliğine sahip olabilir (Aydın, 2014, s. 25). Bireylerin değişimlere etkili bir şekilde uyum sağlayabilmesi ve kendilerini gerçekleştirebilmelerinde eğitim sistemine, dolayısıyla okullara önemli görev ve sorumluluklar düşmektedir (Şahin, 2005).

Okullarda eğitim öğretim hizmetlerinin belirlenen amaç ve hedeflere uygun olarak yerine getirilmesinde görevli olan kişi okul müdürüdür. Eğitim ve öğretim etkinliklerinin gerçekleştirilme düzeyi ve bu etkinliklerin hedeflenen çıktılara ulaşmasını sağlamak için okul müdürünün yapacağı etkili yönetim denetimle mümkün olur ve yönetim süreçlerinin önemli bir basamağı olduğundan denetim gerekli bir fonksiyondur (Yeşil, 2018). Altıntaş (1992) tarafından eğitim denetimi; eğitim kurumunun sahip olduğu madde ve insan kaynaklarının önceden belirlenmiş mevzuata, kurumun amaçlarına, eğitim-öğretim ilkelerine ve ekonomik tedbirlere uygun olarak gerçekleşip gerçekleşmediğini, ayrıca eğitim örgütünde meydana gelen sorunları tespit edip değerlendirmek olarak tanımlanmıştır. Bu bakımdan, eğitimde gerçekleştirilen denetim, eğitim-öğretimin kendisinden beklenen amaçlara uygunluğunun kontrol edilmesi ve eğitim çıktılarının nitelik ve nicelik yönünden geliştirilmesini sağlamak amacını gütmelidir. Bir eğitim kurumunda yapılan denetimin temel fonksiyonu öğretme ve öğrenmenin gerçekleştirildiği ortamın analizinin yapılması, ortamın değerlendirilmesi ve sürecin geliştirilmesi vasıtasıyla hedeflere ulaşılmasının sağlanmasıdır. Eğitim denetimi eğitim kurumlarında görev yapan yönetici, uzman ve öğretmenlerin meslek gelişimlerini teşvik ederek sorularına çözüm yolları bulunmasına yardım eden, davranışların eğitim ve değerlendirmeyle bir süreç olarak değiştirilebileceği, anlayışıdır. Denetim yapan kişi denetimini gerçekleştirdiği bireyin işinde daha başarılı olabilmesi ve gelişim sağlayabilmesi için bireyle veya grupla çalışmasında önerilerde ve katkıda bulunarak hem rehberlik yapar, hem mesleki yardımda bulunur, hem de iş başında yetiştirir (Taymaz, 2015, s. 91). Eğitim denetimini zorunlu kılan bir diğer önemli hususta denetimin günümüzde artık kontrol etmekten ziyade geliştirme odaklı bir işlev olarak görülmesidir. Bu çerçeveden bakıldığında bilhassa öğretimin denetlenmesi ve geliştirilmesi eğitim sisteminin kendisinden beklenen amaçlarına ulaşmasında en gerekli unsurlardan biri haline gelmiştir (Aydın 2016, s. 3).

Türkiye'de öğretmenlerin denetlenmesi son yıllara kadar, MEB teşkilatının içerisinde bir alt birim olarak kurulan teftiş kurul başkanlığına bağlı olan, bakanlık müfettişleri ve eğitim müfettişleri vasıtasıyla yapılmaktaydı. Eğitim sistemindeki yaşanan gelişmeler ve yeniliklerden dolayı denetim sisteminin yapısı ve işleyişinde zaman zaman yeni düzenlemelere gidilmiştir. 2010 ve 2011 yıllarında yapılan kanun ve yönetmelik değişikliği ile denetim sisteminde eğitim müfettişi, eğitim denetmeni en son olarak maarif müfettişi olarak isim değişikliği yapılmış ayrıca rehberlik ve denetim, inceleme ve soruşturma alanlarında yapılan değişiklikler ile eğitim denetçilerinin görevleri tekrar düzenlenmiştir. En son 2014 ve 2016'da yapılan düzenlemelerin ardından maarif müfettişlerinin geçmişten buyana temel görevlerinin arasında yer alan öğretmen denetimi yer almamaktadır. Dolayısıyla, öğretmenlerin ders denetimi görevi daha önce belirlenen mevzuat gereğince tekrar okul müdürlerine bırakılmıştır. Bu değişimle beraber, okul müdürlerinin ders denetimi yapmaları konusu, yeterlilik ve nitelik gibi konularla ilişkilendirilerek tartışımaya başlanmıştır. Şu anda geçerli olan mevzuat uyarınca öğretmenin iş başında denetim görevinin de artık okul yöneticileri tarafından yapılması istenmektedir (MEB, 2000; Ergen ve Eşiyok, 2017).

Okul yöneticilerinin görevleri arasında yer alan öğretmen denetimi iki temel amaca dayanır. Bunlardan ilki, etkili eğitimin sağlanmasına yardımda bulunmaktır. Okullarda yürütülen eğitim faaliyetlerinin her bakımdan amaçlarına uygun olarak, etkili ve verimli olarak gerçekleştirilmesine çalışlır. İkinci amaç ise ders teftişi dediğimiz bir eğitim kurumunda öğretici olarak görev yapan öğretmenlerin öğretim ve eğitim faaliyetlerindeki çalışmalarının gözlenmesi, incelenmesi ve değerlendirilmesidir. Denetmenlerin yaptıkları ders teftişleri öğretmenlerin öğretim yapma ve ders vermedeki başarılarını değerlendirmenin yanında öğretmenlerin davranış eksikliklerinin giderme, yeteneklerini geliştirme, mesleğe ve çevreye uyumlarını sağalama, eğitim alanındaki yenilik ve değişiklikleri öğretmenlere tanıtma yoluyla onlara mesleki yardımda bulunarak, öğretmenin mesleki durumu hakkında karar vermektir. Yöneticinin bu amaçlara ulaşması öğretmenin mesleki olarak gelişmesini sağlayarak mevcut performansının arttırılmasına yardımcı olur (Taymaz, 2015, s. 30-93; Özmen, 2000, s. 121). Öğretmen denetimi öncelikli olarak öğretimin geliştirilmesini merkeze alan şekillendirici bir süreçtir. Yalnızca öğretmenin öğretim yapmadaki başarı düzeyini değerlendirmekle kalmayarak ayrıca denetim sonucunda öğretmenin eksikliklerini belirmeyi ve gidermeye, yeteneklerini geliştirmeye 
yönelik faaliyetleri de kapsar. Öğretim alanındaki denetleme, öğretmenlerin mesleki gelişimlerini de desteklediğinden dolayı rehberlik anlamına gelir (Kalule ve Bouchamma, 2013, s. 90; Alila, Uusiautti ve Määttä, 2016, s. 351; akt.Yeşil, 2018; s. 5).

Günümüze baktığımızda dünya ülkelerinde eğitimde nitelik, en önemli sorunların başında gelmektedir. Öğretmenin niteliği de eğitimde niteliğin ana bileşenidir. Açıkçası eğitimde nitelik, en başta öğretmenin nitelikli olmasıyla olanaklıdır. Onun için diğer ülkelerde ve Türkiye'de öğretmeni nitelikli yapmanın arayışı sürekliliğini korumaktadır. Öğretmenin niteliğini etkileyen etmenlerden biri hizmet öncesi öğretmen eğitimidir. Öğretmenlerin hizmet öncesinde aldıkları eğitimin mesleği tüm gereklerinin yerine getirmelerinin sağlayamadığı bir gerçektir. Öğretmenlerin kusursuz yetiştirildiği varsayılsa bile meslekteki yeni gelişmeleri takip edip, uyum sağlamaları ve çevresel koşulların gereklerini yerine getirebilmeleri öğretmenlerin sürekli eğitimini zorunlu kılmaktadır. íkincisi, hizmet içi yani iş başında öğretmen eğitimi, daha güncel deyişiyle öğretmenlerin mesleki gelişimidir. Mesleki gelişim, öğretmenlerin mesleklerini yaptıkları sıradaki yenileyici ve genişletici öğrenmelerdir. Dünyadaki değişmeler ve gelişmeler, mesleki gelişimin önemini giderek artırmaktadır (Özer, 2008, s. 195). Öğretmenin görev başında geliştirilmesi ve değişmesine katkıda bulunulması artık bir tercih olmaktan çıkarak, içinde bulunduğumuz bilgi çağının öğretmenin rolünün öngördüğü bir zorunluluğa dönüşmüştür. Bu günümüz zorunluluğunun önemi tartışımaz bir gerçektir. Tartışılması gereken nokta öğretmenin sürekli olarak geliştirilmesi için öngörülen hizmet içi eğitim ve personel geliştirme programının nasıl olması ve denetimin bu konuda nasıl işlev üstlenmesi gerektiği durumudur(Aydın, 2014, s. 167). Bundan dolayı, denetimin öğretmenlerin mesleki gelişimine yönelik etkisi konusunun bilimsel bir zeminde araştırılması gerekli görülmüştür. Bu bağlamda öğretmenlerin görüşlerine göre okul müdürlerinin denetim yeterliliğini ve denetimin öğretmenlerin mesleki gelişimlerine etkisini ortaya koymak ve denetim sistemine yönelik öneriler geliştirmek amaçlanmıştır.

\section{Yöntem}

\section{Araştırmanın Modeli}

Bu araştırmanın modeli görüşme, gözlem ve belge analizi gibi nitel veri toplama yöntemlerinin kullanılarak, var olan algı ve olayların doğal ortamda gerçekçi bir şekilde ve bütüncül olarak meydana çıkarılmasına yönelik nitel bir sürecin takip edildiği araştırma olarak tanımlanan nitel araştırmadır (Yıldırım ve Şimşek, 2011, s. 39). Nitel araştırma desenlerinden de tamamıyla yabancısı olunmayan fakat tam manasıyla da kavranılamayan fenomenleri araştırmayı amaçlayan olgu bilim deseni kullanılmıştır.

\section{Çalışma Grubu}

Araştırmanın çalışma grubunu 2018-2019 eğitim-öğretim yılında Bolu merkez ilçe ilkokul, ortaokul ve ortaöğretim devlet okulların da görev yapan 10 ilkokul, 13 ortaokul ve 7 ortaöğretimde görev yapan toplam 30 öğretmenden oluşmaktadır. Çalışma grubunun cinsiyet değişkenine göre; 17'si kadın 13'ü erkektir. Mezuniyet durumuna göre lisans mezunu olan 23 kişi, yüksek lisans mezunu 7 kişidir. Alan değişkenine göre sınıf öğretmeni 7 kişi, branş öğretmeni 23 kişidir. Kıdem değişkenine göre kıdemi 5 yıl olan 3 kişi, 6-10 yıl olanlar 8 kişi, 11-15 olanlar 11 kişi, 16-20 yıl olanlar 4 kişi, 21-25 yıl olanlar 2 kişi, 25 yıldan fazla olan 2 kişidir. Araştırma da olasılık dışı örnekleme çeşitlerinden olan ölçüt örnekleme kullanılmıştır. Bu örneklemede esas anlayış kimlerin seçilebileceği hususunda araştırmacının önceden belirlendiği bir takım ölçütleri karşılayan ve araştırmanın amacına en uygun olan örneklemi kullanmaktadır (Yıldırım ve Şimşek, 2005). Bu doğrultuda bütün okul türlerinden katılımcıya ulaşılmasına, en az 5 yıllık öğretmenlik kıdemine sahip olmasına ve araştırmaya katılıma gönüllü ve istekli olmasına dikkat edilerek hareket edilmiştir.

\section{Veri Toplama Aracı}

Araştırmada, öğretmenlerin görüşlerini belirlemeye yönelik yarı yapılandırılmış görüşme formu kullanılmıştır. Bu formla yapılan görüşmeler, ne tam yapılandırımış görüşmeler kadar katı özelliğe sahip ne de yapılandırılmamış görüşmeler kadar esnek olup; iki uç arasında yer almaktadır (Karasar, 2012).Veri toplama aracı oluşturulurken araştırma konusuyla ilgili olarak alan yazın incelemesi yapılmış ayrıca konu alanı uzmanı olan kişiler ile görüşmeler yapılmış olup önerilerinden yararlanılmışır. Elde edilen bilgiler ışığında formda yer alması düşünülen sorular belirlenerek taslak form hazırlanmış, konuyla ilgili uzman üç kişinin görüşlerinden faydalanılmıştır. Oluşturulan form ile katılımcı grubu haricindeki 5 öğretmene ön çalışma yapılmıştır. Gerçekleştirilen uygulama neticesinde formdaki soruların katılımcılarca araştırma amacına uygun olarak doğru anlaşıldığı görülmüştür. Elde edilen verilerin literatürle karşılaştırması yapılarak doğruluğu kontrol edilmiş ve araştırma formuna son şekli verilmiştir. Katılımcıların sorulara rahat cevap verebilmelerini sağlamak için her bir katılımcıya adlarının araştırmada açık şekilde kullanılmayacak olduğu ve elde edilen verilerin kimseyle paylaşılmayacağı belirtilerek kodlanarak kullanılacağı iletilmiştir. Veri toplama 
aracında katılımcılara şu sorular yöneltilmiştir; denetim kavramının ne ifade ettiği, okul müdürünün ders denetimine yönelik yeterliliği hakkındaki görüşlerinin ne olduğu, okul müdürünün ders denetiminde öğretmenleri olumsuz etkileyen durumların olup olmadığı varsa neler olduğu, okul müdürünün ders denetiminde öğretmenlerin mesleki gelişimine katkısı olup olmadığı varsa neler olduğu ve denetimin kimler tarafından nasıl yapılması gerektiği sorulmuştur.

\section{Verilerin Çözümlenmesi ve Yorumlanması}

Araştırmada verilerin analiz sürecinde katılımcıların görüşlerinin tahlil edilmesinde nitel veri analiz yöntemlerinden olan betimsel ve içerik analizinden yararlanılmıştır. Veri analizinde de verilerin kodlanması, kodlanmış verilerde temaların belirlenmesi, kodların ve temaların düzenlenmesi, bulguların tanımlanması ve yorumlanması (Yıldırım ve Şimşek, 2011) olmak üzere 4 aşama izlenmiştir. Analiz sürecinde öncelikli olarak, görüşme formların çözümlenmesi yapılmıştır. Katılımcıların görüşlerinin analizinde, ifadelerin benzerliğine göre gruplamalar yapılmıştır. Çözümlemelerde görüşüne başvurulan öğretmenlere $(0 ̈ 1, O ̈ 2)$ şeklinde kodlar verilmiştir. Bulgular sunulurken bir kavramın veya düşüncenin kaç kez tekrar ettiği görüş sıklığıyla ve çarpıcı görüşlerle birlikte tablolaştırılarak ifade edilmiştir. Ayrıca araştırmanın geçerlilik ve güvenirliliğinin yönelik olarak, kuramsal çerçeve dâhilinde kategoriler belirlenmiş, verilerin analiz sürecinde kodlamanın yapılması ve kategorilerin belirlenmesinde iki araştırmacı tarafından bağımsız bir biçimde ayrı ayrı yapılmıştır. Araştırma sonucunda ulaşılan verilerin güvenirliliğini kontrol etmek için birey bazında analizlerin sonuçlarında görüş birliğine ulaşan araştırmacılar, görüş birliği oranını hesaplayabilmek için "Görüş Birliği/(Görüş Birliği+Görüş Ayrılı̆ıı)x100" (Miles ve Huberman, 1994) formülünü kullanarak, öğretmen görüşlerine ilişkin analizlerde \%85 oranında görüş birliğine ulaşmışlardır. Yıldırım ve Şimşek'e (2011) göre, güvenirlik hesaplamasındaki uyuşum yüzdesi \%70 olduğunda güvenirlik yüzdesine ulaşımış kabul edilir. Dış güvenirlik için verilerin analizinde kullanılan kavramsal çerçeve, analiz yöntemleri ile ilgili ayrıntılı açıklamalara yer verilmiştir.

\section{Bulgular}

Araştırmanın bu bölümünde görüşme formlarından ulaşılan veriler doğrultusunda denetim kavramı, okul müdürlerinin denetim yeterliliği, denetimde yaşanan olumsuzluklar, denetimin mesleki gelişime etkisi ve denetim sisteminin geliştirilmesine yönelik katılımcıların görüşleri sırasıyla sunulmuş ve yorumlanmıştır.

\section{Denetim kavramı algısı}

Katılımcıların, denetim kavramına ilişkin görüşleri Tablo1'de gösterilmiştir.

Tablo 1. Denetim kavramına ilişkin öğretmen görüşleri

\begin{tabular}{llll}
\hline Tema & Kategori & $\mathbf{f}$ & $\mathbf{\%}$ \\
\hline & -Kontrol mekanizması & 12 & 40 \\
& -Kriterlere göre değerlendirme & 6 & 20 \\
Denetim Kavramı & -Yapılanların gözlemlenmesi & 4 & 13 \\
& - Inceleme/takip işi & 4 & 13 \\
& -Araştırma ve soruşturma & 3 & 10 \\
& -Belirleme ve düzeltme işi & 1 & 4 \\
\hline
\end{tabular}

Tablo 1' de görüldüğg̈ gibi denetim kavramına ilişkin olarak öğretmenlerin görüşleri; denetim kontrol mekanizmasıdır $(f=12)$, denetim kavramı kriterlere göre değerlendirme işidir $(f=6)$, denetim yapılanların gözlemlenmesidir ( $f=4)$, denetim inceleme/takip işidir $(f=4)$, denetim araştırma ve soruşturmadır $(f=3)$ ve aksaklıkları belirleme ve düzeltme işidir $(f=1)$ yönünde görüş belirtmişlerdir. Denetim kavramına ilişkin görüş bildiren öğretmenlere ait bazı ifadelere aşă̆ıda yer verilmiştir;

"Denetim eğitim öğretim faaliyetlerinin ne ölçüde yapıldığı, yapılırken kullanılan yöntem ve tekniklerin uygunluğu, belirlenen hedeflere zamanında ulaşılıp ulaşılmadığı sınıf yönetiminin nasıl yapıldığı öğretim programlarının uygulanıp uygulanmadığı gibi durumların gözlenmesi ve bu gözlemlerin değerlendirilmesi olarak ifade edilebilir."(Ö5);

"inceleme, araştırma, soruşturma, doğruyu bulmak için yasal çerçevede yapılan çalışmalardır."(Ö15);

"Plan ve program çerçevesinde yapılması gerekenlerin kontrol edilmesi demektir. Görevlerin yerine getirilip getirilmemesine bakılan bir mekanizmadır."(Ö6);

"Denetim bana göre her işte ve alanda en iyi sonuca varmak, verimliliği artırmak için yapılan kontrollerdir. Denetimsiz düzen, disiplin ve başarı sağlanamaz. Kendi akışına ya da insanın kendi tasarrufuna bırakılmış işler denetlenmediğinde olumsuz sonuçlar doğurabilir. Aslında denetim kelimesiyle hep dışarıdan yapılan bir eylem gibi 
gelse de insan kendini de denetleyebilir. Tabi o davranış biçimine ahlaka sahipse. Kısaca bir işte mükemmele, doğru olana, düzene ve başarıya ulaşmak için yapılan kontrollerdir."(Ö11);

"Denetim bireysel anlamda yapılan işin örgütsel anlamda da amaçların ne denli yerine getirildiğini dair değerlendirme sürecidir. Amacın ve planın soncuna yönelik olumlu işler oluşturabilmek için denetimin şart olduğunu düşünüyorum."(Ö12);

"Denetim yapılan işin incelenmesidir. Eğitim-öğretimde bence denetim olmalıdır, hatta denetimler sonucunda yetersiz görülen eksikliği tespit edilen öğretmenlere kapsamı olan eğitimler verilmelidir."(Ö21);

"Denetimi kurum bazında açıklamak istersem, yürütülen iş veya verilen hizmetlerin yeterliliği konusunda o kurumun idari hiyerarşideki her bir üst birimin alt birimleri gözlemlemesidir. Dikkati çeken eksikliklere ya da yanlışlıklara zamanında müdahale edilmesi hususunda "denetim" çok önemlidir."(Ö30).

20.yüzyıl başlarında uygulanmaya başlanılan bilimsel yönetim anlayışı eğitim yönetimi ve denetimini de etkilemiştir. Amerikalı eğitimci Franklin Bobbit yönetim ilkelerinin okul denetimine uygulanmasını ilk gerçekleştirenlerdendir. Bu denetim anlayışında eğitim hedeflerinin açık olarak tanımlanması ve hedefler doğrultusunda eylemlerin gerçekleştirilmesi öngörülmektedir. Bilimsel yöntemin uygulanmasında öğretmen kendi dışında oluşturulan ilke ve yöntemlere göre rolünü oynama durumundadır. Burada dikkat çeken durum öğretmenin yetersiz olduğu sayıltısından yola çıkarak denetmen yönlendiren, öğretmende yönlendirilen durumundadır. Ancak günümüzde çağdaş denetim yaklaşımına baktığımızda ise Wiles (1967) denetimi öğretmenlere daha iyi görev yapmaları için olumlu insan ilişkilerini vurgulayan karşılıkl, iletişim ve etkileşime dayalı, kişilerin birbirini dikkate aldığı, sorun çözme ve geliştirmeye dayanan öğretmeni destekleme ve yardım hizmetidir. (Aydın, 2014, s. 2-7). Öğretmenlerin çoğunluğu tarafından denetimin kontrol mekanizması olarak algılanması çağdaş denetimden uzak, yüzyıl öncesi bilimsel yönetim anlayışına yakın olduğu söylenebilir. Buradan öğretmenlerin denetiminde rehberlik ve onların sorunları ve öğretmenlerin eksiklerinin giderilmesinin çok üzerinde durulmadığı sonucuna ulaşılabilir.

\section{Okul müdürlerinin denetim yeterliliği}

Katılımcıların, okul müdürlerinin denetimde yeterli olup olmamalarına ilişkin görüşleri Tablo 2'de gösterilmiştir.

Tablo 2. Okul müdürlerinin denetim yeterliliğine ilişkin öğretmen görüşleri

\begin{tabular}{|c|c|c|c|c|}
\hline Tema & $f$ & $\%$ & Kategori & $f$ \\
\hline $\begin{array}{l}\text { Ders denetimi } \\
\text { yeterli }\end{array}$ & 8 & 27 & $\begin{array}{l}\text {-Fikir alış verişi yapma } \\
\text {-iletişimi iyi olma } \\
\text {-Hoş görülü ve iyi niyetli } \\
\text {-Objektif davranma } \\
\text { - Öğretmeni daha iyi tanıma } \\
\text {-Aksaklıkları düzeltmeye çalışma } \\
\text {-Tecrübeli olma }\end{array}$ & $\begin{array}{l}2 \\
1 \\
1 \\
1 \\
1 \\
1 \\
1\end{array}$ \\
\hline $\begin{array}{l}\text { Ders denetimi } \\
\text { yetersiz }\end{array}$ & 22 & 73 & $\begin{array}{l}\text {-Alan bilgisi eksik olma } \\
\text {-Branş farklılıkları } \\
\text {-Bilgi birikimi ve donanıma sahip } \\
\text { olmama } \\
\text {-Formalite görev yapma } \\
\text {-Sadece sınıf yönetimi denetleme } \\
\text {-Eleştirel bakma } \\
\text {-Derse girmeme /çok az girme }\end{array}$ & $\begin{array}{l}3 \\
2 \\
2 \\
1 \\
1\end{array}$ \\
\hline
\end{tabular}

Tablo 2' de görüldüğü gibi katılımcıların 8 tanesi okul müdürünün ders denetimini yeterli bulurken, 22 kişi ders denetimini yetersiz bulduğuna dair görüş belirtmişlerdir. Ders denetiminin yeterli olduğuna ilişkin görüşleri; fikir alış verişi yapma ( $f=2)$, iletişimi iyi olma $(f=1)$, hoş görülü ve iyi niyetli olma $(f=1)$, objektif davranma $(f=1)$, öğretmeni daha iyi tanıma $(f=2)$, aksaklıkları düzeltmeye çalışıyor $(f=1)$, tecrübeli olma $(f=1)$.

Ders denetiminin yetersiz olduğuna ilişkin görüşleri; Alan bilgisinin eksik olması $(f=9)$, branş farklılıkları ( $f=1)$, bilgi birikimi ve donanıma sahip olmama $(f=2)$, formalite görev yapma $(f=6)$, sadece sını $f$ yönetimi denetleme $(f=3)$, eleştirel bakma $(f=1)$, derse girmeme çok az girme $(f=1)$ yönünde görüş belirtmişlerdir.

Okul müdürlerinin denetim yeterliliğine ilişkin görüş bildiren katılımcılara ait bazı ifadelere aşağıda yer verilmiştir; 
"Okul müdürüm, branş olarak farklı olsak da, dersimle ilgili denetim konusunda yeterli şekilde fikir alışverişinde bulunabildiğim bir denetçidir. Müdahale etmesi ya da fikir beyan etmesi gerekli olduğunda, bu okula başladığım ilk günden itibaren oluşturduğumuz ortak dil sayesinde, gayet başarılı iletişimlerde bulunabiliyoruz."(Ö30);

"Okul müdürlerinin geçmişlerinde öğretmenlik mesleğinin mevcut olması özellikle ders denetiminde öğretmeni en iyi anlayacak yorumlayacak ve değerlendirecek yeterliliğe sahip olması beklenir."(Ö7);

"Okul müdürü elinde belirlenen kriterlere göre öğretmenleri denetlemektedir. Okul müdürünün yeterliliği bütün branşlarda olması mümkün değildir. Fakat iyi niyetli olarak gördüğü aksaklıkları düzeltmeye çalışmaktadır."(Ö19)

Okul müdürünün denetimde yetersiz olduğuna yönelik görüş bildiren katılımcılara ait bazı ifadeler;

"Okul müdürleri görevli bulundukları okuldaki tüm öğretmenlerin rehberlik ve mesleki gelişim ihtiyacını karşılayabilecek bilgi birikimine ve donanımına sahip olmalıdır. Ders denetimi sırasında hedef ölçme değerlendirme değil rehberlik edebilmek olmalıdır. Mesleki hayatı boyunca uygulama alanında bulunmayan ya da akademik olarak lisans seviyesi üstünde çalışmalar yapmamış kişilerin bu denetimi yapacak donanıma sahip olması çok zor olup somut bir yeterlilik değerlendirmesi yapılması beklenmez. Örnek olarak mesleki hayatı boyunca hiç sınıfa girmemiş ders anlatmamış, öğretim sürecinde öğrenci motivasyonunu yüksek tutabilme yollarını deneyimlememiş ya da çocuk ile nasıl sağlıklı iletişim kurulabileceği hakkında yeterli bilgiye sahip olmayan bireylerin öğretmenlerin uygulamalarını değerlendirmesi."(Ö8);

"Okul müdürlerinin bir öğretmenin öğretmenlik uygulamasını denetlemesi noktasında yeterli olabileceğini ancak alan bilgisi denetiminde eksik kalacağını düşünüyorum. Şayet örneklendirecek olursak benim sınıf içinde öğrenciye karşı iletişimimi sınıf içindeki tutum ve davranışlarını değerlendirebilir, fakat 'basit makineler' konusunu anlatırken ne düzeyde etkili bir öğretim gerçekleştirdiğimi karar vermesi zor. Çünkü alan bilgisi gerektirir."(Ö4);

"Ders denetimi yapılırken belirlenen kriterler hakkında okul müdürünün de yeterli bilgi ve donanıma sahip olması gerekir. Kanunlar ve yönetmelikler yanında dersini denetlediği öğretmenin branşı ile ilgili temel bir bakış açısına sahip olmalıdır. Öğretmeni denetleyen konumunda değil bilgi ve deneyimleri ile rehberlik edebilen bir konumda olmalıdır. Ders denetimindeki yeterlilikler belirlenen kriterler ile ortaya çıkacaktır. Genel olarak ders denetimi resmi bir prosedür olarak yapılmaktadır."(Ö5);

"Okul müdürünün yaptığı denetimi formalite icabı ya da yapması gereken bir görev olduğu için yaptığını düşünüyorum. Sadece çok bariz olan hataları görebilir ."(Ö18);

" Öğretmenlik mesleğinin genel ilkeleri bakımından yeterlikleri bulunsa da öğretmenlik mesleğini tam yerine getiremeyen derse girmeyen ya da çok az derse giren okul idarecisi bence denetimde yetersiz kalmaktadır. MEB tarafından denetim kriterleri hazırlanmasa denetimcinin işi oldukça zor olur diye düşünüyorum. Branş farklılıkları bu işi zorlaştırmaktadır. Okul müdürünün her dersin programına hâkim olması mümkün değildir ."(Ö6);

"Şuana kadar açıkçası bu yeterliliğe sahip bir müdür göremedim. Tabiki onlarda bir zamanlar bizim gibi öğretmendiler. Hepsi farklı branşlarda bilgili ama idarecilik konusu bambaşka. Yani okulda birçok branşta öğretmen arkadaş var ve okul müdürü sadece kendi branşıyla ilgili olan öğretmeni denetleyebilir. Uzun süre okul müdürlüğü yapanlar kendi branşlarında ki bilgilerini bile unutmuş olabilir. Örnek verecek olursam beni denetleyen müdürler ingilizce konusunda yeterli bilgiye sahip değillerdi ve ben ders anlatırken ya başka şeyle uğraşıyorlar ya da boş boş bakıyorlardı. Bu konuda beni denetlemede yetersizdiler. Bazı genel mekanik unsurları kontrol ediyorlardı. Defter tam mı? Kazanım yazılmış mı? Sınıf yönetimi nasıl? gibi..."(Ö11);

"Okul müdürlerinin ders denetimi konusunda yeterli denetime sahip olduklarını düşünmüyorum. Bizdeki denetimler daha çok eksik bulma amacıla yapılıyor. Denetlemeler sonucunda öğretmenleri destekleyici ve motivasyonlarını arttırmaya yönelik çalışmalar yerine cezalandırıcı bir denetim mekanizması hâkim gibi görünüyor. Denetim yapacak müdürlerin bu konuda yeterli alt yapısı olmalıdır."(Ö13)

Dağ (2016) çalışmasında okul müdürlerinin denetimine yönelik öğretmen algılarında en çok öne çıkan görüşün yasal düzenlemeleri (yasa ve yönetmelikleri) bilir, uygular, yasal ödevlerini yerine getirirken kanun ve yönetmeliklere göre hareket eder sonucuna ulaşmıştır. Ergen ve Eşiyok (2017) ise çalışmasında öğretmenlerin okul müdürlerinin denetimine ilişkin görüşlerinin katılıyorum düzeyinde olduğu sonucuna ulaşmışlardır. Köybaşı, Uğurlu, Bakır ve Karakuş (2017) çalışmasında katılımcıların okul müdürünün ders denetimini yaparken işinin uzmanı olup olmasına ilişkin öğretmen görüşlerini sorgulamış olup katılımcıların yarısına yakının okul müdürlerinin ders denetiminde uzman olmadığını bu netice de denetim sonuçlarının çok sağlıklı olmadığı şeklinde belirtmiştir. Bayar (2017) görevlendirilen okul müdürlerinin birçoğunun ders denetimi ve rehberlikle ilgili bir eğitim almamış olmasından dolayı etkili ders 
denetimi yapılamayacağı intimaline dikkat çekmiştir. Bu çalışma bulguları araştırma sonuçlarıyla paralellik göstermektedir.

Okul müdürlerinin görevleri sadece okulun mali ve bürokratik işlerini yürütmek değil en az bunun kadar önemli olan okul müdürlerinin öğretim liderliği rolleridir. Bu manada okul müdürlerinin sınıf içi etkinlikleri denetlemeleri, öğretmenler ile yakın bir ilişki kurmaları, onlara rehber olmaları gerekmektedir. Doğaldır ki bütün bu etkinliklerin amacı eğitim-öğretim etkinliklerinin geliştirilmesidir.

Ders denetiminin amaçları MEB ilköğretim müfettişleri başkanlıkları rehberlik ve teftiş yönergesinin 20.maddesinde öğretmenlerin ders teftişinde göz önünde bulundurulacak hususlar şöyle sıralanmıştır; eğitim-öğretim faaliyetlerindeki başarı düzeyiyle ilgili bilgi sahibi olmak, olumlu tutum ve davranışlarını belirleyerek, vazifesini en iyi şekilde gerçekleştirebilmesi için özendirmek, eğitim ve öğretimde birliğin sağlanması için rehberlik ve yardımda bulunmak, okulda yapılan öğretim faaliyetleri, metot ve tekniklerini analiz ederek geliştirmek, öğretim aşamasında kullanılacak materyallerin temin edilmesinde ve kullanılmasında destek olmak, öğrenci akademik başarısına yönelik olarak elde edilen bulguların ölçülmesi ve değerlendirilmesinde çağdaş ve ilmî yöntemler ile yardımcı olmak, var olan veya karşılaşılan problemlerin çözülmesinde yol göstermek. Özel eğitim ihtiyacı olan bireylere yönelik almış olduğu tedbirleri geliştirmek ve yönlendirmek, sınıf içerisinde ve çevredeki eğitimsel liderliğinin belirlenmesi için yapılır (Demir, 2009). Bu kadar okulun verimliliği için önemli işleve sahip olan bir görevin bilgi ve yeterlilik olarak zayıf idareciler tarafından yürütülmesinin öğretmenlerin olumsuz düşüncelere sahip olmasında etkili olduğu söylenebilir.

\section{Denetimde yaşanan olumsuz durumlar}

Katılımcıların okul müdürlerinin denetiminde olumsuzluk yaşayıp yaşamama durumlarına ilişkin görüşleri Tablo 3'te gösterilmiştir:

Tablo 3. Okul müdürünün denetiminde yaşanan olumsuzluklara ilişkin öğretmen görüşleri

\begin{tabular}{|c|c|c|c|c|}
\hline Tema & $f$ & $\%$ & Kategori & $f$ \\
\hline $\begin{array}{l}\text { Ders denetimi } \\
\text { olumsuzluk } \\
\text { yaşıyorum }\end{array}$ & 8 & 27 & $\begin{array}{l}\text {-Evrak takibi için sınıfa gelme } \\
\text {-Eksiklikleri sınıf ortamında söyleme } \\
\text {-Habersiz denetim } \\
\text {-Ders akışını bozma } \\
\text {-Öğrencilere müdahale } \\
\text {-Üstünlük kurma çabası } \\
\text {-Öğrencilerin tedirgin olması }\end{array}$ & $\begin{array}{l}2 \\
1 \\
1 \\
1 \\
1 \\
1 \\
1\end{array}$ \\
\hline $\begin{array}{l}\text { Ders denetimi } \\
\text { olumsuzluk } \\
\text { yaşamıyorum }\end{array}$ & 22 & 73 & $\begin{array}{l}\text {-Herhangi bir olumsuzluk yaşamama } \\
\text {-Motivasyon düşürücü bir durum yaşamama } \\
\text {-Ders denetimi geçirmeme }\end{array}$ & $\begin{array}{l}17 \\
3 \\
2\end{array}$ \\
\hline
\end{tabular}

Tablo 3' de görüldüğü gibi katılımcıların 8 tanesi okul müdürünün ders denetiminde olumsuzluk yaşadığını belirtirken, 22 kişi ders denetiminde olumsuzluk yaşamadığına dair görüş belirtmişlerdir. Ders denetiminde olumsuzluk yaşadığına ilişkin görüşleri; Evrak takibi için sınıfa gelme $(f=2)$,eksiklikleri sınıf ortamında söyleme ( $f=1)$, habersiz denetim $(f=1)$, ders akışını bozma $(f=1)$, öğrencilere müdahale $(f=1)$, üstünlük kurma çabası $(f=1)$, öğrencilerin tedirgin olması $(f=1)$.

Ders denetiminde olumsuzluk yaşamadığına ilişkin görüşleri; Herhangi bir olumsuzluk yaşamama ( $f=17)$, motivasyon düşürücü bir durum yaşamama $(f=3)$, ders denetimi geçirmeme $(f=2)$ görüş belirtmişlerdir. Okul müdürlerinin ders denetiminde yaşanan olumsuzluklara ilişkin görüş bildiren katılımcılara ait bazı ifadelere aşağıda yer verilmiştir;

"Bu konuda benim yaşadığım bir olumsuzluk yok ama şöyle bir şey hatırlıyorum; bir arkadaşım ders işlerken müdür bey ansızın derse girip arka sırada oturmuş ve beş ya da on dakika sonra hoca hanıma hiçbir şey söylemeden ya da hiç yorum yapmadan kapıyı çarpıp çıkmış. Bu olay arkadaşımı çok etkilemişti ve çok üzülmüştü. Okul müdürü en azından dersi tam dinlemeli ve sonra denetim yaptığı öğretmeni kırmadan gözlemlediği eksiklikleri ve aksaklıkları hocaya anlatmalı ve birlikte bir çözüm yolu bulmalıdırlar."(Ö1);

"Teknik noktalarda yapılacak denetimin ders dışında bire bir yapılmasını isterim eğer ders sırasında evrak takibi plan program denetimi yapılacaksa öğrencilerle birlikte sınıfta çok sevimli olmuyor. Sınıf içerisinde sadece ders uygulamasının izlenip çıkılmasının daha uygun olacağını düşünüyorum. Birde objektif davranmak oldukça hassaslık gerektiren bir durum okul içinde kendine yakın gördügü kişilere yüksek uzak kişilere düşük not verilebilir."(Ö4); 
"Denetim konusunda uzman olmayan birileri tarafından denetlenmek insanın zaman zaman zoruma gidiyor ."(Ö6);

"Ders denetimi esnasında varsa yanlışıklar veya eksiklikler o esnada değil, ders bitiminde özel olarak öğretmen iletilmelidir. Öğrencilerin gözünde rol model olan ve otoritesi olan öğretmenlerin bu itibarlarının zedelenmemesi için bunun yapılması gerekmektedir. Ayrıca ders anlatım esnasında öğretmene karışmamalı dersi bölecek öğretmenin moral motivasyonunu bozacak tutum ve davranışlardan kaçınılmalıdır ."(Ö7);

"Ders denetimi haber verilmeden yapılması durumunda öğrenciler heyecanlana biliyor, genellikle sınıftaki öğrenciler tedirgin oluyor. Denetim sırasında öğretmen ve sınıf arasındaki iletişim biraz doğallığını yitirerek yapay bir hale dönüşüyor. Müdürün sınıf denetlemesi sırasında her sınıfın özelliklerini bilmesi gerekir. Gördügü sıkıntılar varsa bunlara çözüm önerileri sunacak yeterlilikte olmalıdır. Denetim sırasında olumsuz etkilerden biride öğretmeninde öğrencilere yaklaşımı biraz izlendiğini bildiğinden ve yanlış yapma korkusundan dolayı doğallığını yitirmektedir."(Ö13);

"Ben ders anlatırken telefonla görüşmesi, dersin akışını bozması, ben oradayken öğrencilere müdahale etmesi, üstünlük kurma çabaları gibi durumlar beni rahatsız etmişti. Ayrıca habersiz yapılması da beni kızdırmıştı. Aniden sınıfıma girilmesi hoşuma gitmemişti ."(Ö11);

"Okul müdürü ile sağlıklı bir iletişim varsa öğretmenin denetimde öğretmen için bir kâbus olmaz. Fakat okul müdürü öğretmenlerine tepeden bakan sürekli eksik arayan bir insan ise ders denetimi ciddi manada sıkıntı olur ."(Ö2)

Okul müdürü denetiminde olumsuzluk yaşamadığını ilişkin görüş bildiren katılımcılara ait bazı ifadeler;

"Hayır kendisinin de bir öğretmen kökenli olduğu bildiği için empati yapmalıdır. Problemlerin çözümünde iyi niyet ve karşııılı anlayış görev sorumluluğu duygularını bilir ve ona göre denetimini yapar ."(Ö3);

"Olumsuzluk denetimin temel yapısındadır ve daha üstte toplumun genel inanış ve yapısal bozukluğunda denetimin yapan ister okul müdürü ister müfettiş ister de mülkü amir olsun. Çalışma hayatımda türlü denetim birimlerinin denetimine muhatap oldum ve hiçbir denetim bir öncekiyle aynı olmadı. Denetimi yapanların kişisel yapılarının muhatabı olarak denetimler geçirdik. Okul müdürlerim bireysel olarak çalıştığım kurumlarda hiçbir zaman olumsuz bir şeyini görmedim. Fakat denetim anlamında gerçek bir değerlendirmeye hiç tabi kalmadım ."(Ö10);

"Beni olumsuz etkileyen bir durum yok. Çalıştığım müdürler derste bir öğrenci gibi varlıklarını unutturup inceden denetimler yaptı. Bu bence uygun ve yerinde bir davranış olarak nitelendirilebilir."(Ö9);

"Olumsuz herhangi bir durum yaşamadım. Ancak yaklaşık 16 yıldır sınıftaki duruşuma tekniklerime dair bir eleştiri olumlu-olumsuz almamış olmam negatif bir durum. Mutlaka eksiklerim vardır ve bana bunları söyleyecek birisi yok. Zümre arkadaşlarımla olan iletişimim sayesinde eksiklerimi gidermeye çalıştığımı söyleyebilirim."(Ö12).

\section{Denetimin mesleki gelişime katkısı}

Katılımcıların denetimin mesleki gelişimlerine etkisi olup olmadığına ilişkin görüşleri Tablo 4'te gösterilmiştir:

Tablo 4.Denetimin mesleki gelişime katkısına ilişkin öğretmen görüşleri

\begin{tabular}{|c|c|c|c|c|}
\hline Tema & $f$ & $\%$ & Kategori & $f$ \\
\hline $\begin{array}{l}\text { Mesleki gelişime } \\
\text { katkısı vardır. }\end{array}$ & 7 & 23 & $\begin{array}{l}\text {-Göreve yeni başlayanlara katkı sağlama } \\
\text {-Tecrübelerini aktarma } \\
\text { - Teşvik edici üslup kullanma } \\
\text { - Öğretmenlik uygulamalarına katkı sağlama }\end{array}$ & $\begin{array}{l}3 \\
2 \\
1 \\
1\end{array}$ \\
\hline $\begin{array}{l}\text { Mesleki gelişime } \\
\text { katkısı yoktur. }\end{array}$ & 23 & 77 & $\begin{array}{l}\text {-Branşlarımız farklı olması } \\
\text {-iyi öğretmen olmamaları } \\
\text {-sadece belge kontrolü } \\
\text {-yeterli donanıma sahip olmama } \\
\text { - kontrol edilme hissi verme }\end{array}$ & $\begin{array}{l}13 \\
3 \\
3 \\
2 \\
2\end{array}$ \\
\hline
\end{tabular}

Tablo 4' de görüldüğü gibi katılımcıların 7 tanesi okul müdürünün denetiminin mesleki gelişimine katkısı olduğunu belirtirken, 23 okul müdürünün denetiminin mesleki gelişimine katkısı olmadığına dair görüş belirtmişlerdir. Denetimin mesleki gelişimine katkısı olduğuna ilişkin görüşleri; Göreve yeni başlayanlara katkı sağlama $(f=3)$, tecrübelerini aktarma ( $f=2)$, teşvik edici üslup kullanma $(f=1)$, öğretmenlik uygulamalarına katkı sağlama $(f=1)$. 
Denetimin mesleki gelişimine katkısı olmadığına ilişkin görüşleri; Branşlarımız farklı olması ( $f=13)$, iyi öğretmen olmamaları ( $f=3)$, sadece belge kontrolü $(f=3)$, yeterli donanıma sahip olmama $(f=2)$, kontrol edilme hissi verme $(f=2)$ görüş belirtmişlerdir. Okul müdürlerinin denetiminin mesleki gelişime katkısına ilişkin görüş bildiren katılımcılara ait bazı ifadelere aşağıda yer verilmiştir;

"Daha önceki okulumda denetim için bir gün ansızın müdürüm içeri girip arka sırada oturmuştu ve ben dersimi kaldığım yerden işlemeye devam ettim. Ders bitiminde müdürümle sınıftan çıktığımızda fenden ne kadar çok bilmediğim şey varmış, yarım saatte bile ne kadar çok şey öğrendim demiştim. Bu benim çok hoşuma gitmişti ve olumlu anlamada beni güdülemişti."(Ö1);

"Henüz otokontrole sahip olmayan bir öğretmen müdürün ders denetimleri sayesinde deste ne yapıp ne yapmayacağını davranış biçimi haline getirebilir. Tabi ki öğretmenler birileri beni denetleyecek korkusuyla değil de işini layıkıyla yerine getirme kaygısılla hareket edecek olgunluğa erişene kadar müdürlerin denetlemelerinden geçmesi katkılı olacaktır. Burada en önemli husus müdürün egoya kapılıp öğretmeni sıkmaması olacaktır."(Ö9);

"Ders denetimi yeterlilik sahibi kişilerce yapıldığı sürece vardır. Ders denetimi farklı bir bakış açısı geliştirebilmemi zaman yönetimindeki durumumu, motivasyon durumumu özgüven seviyemi ölçmemi değerlendirmem ve geliştirmem için büyük bir fayda sağlayıcı olacaktır."(Ö8) ;

"Göreve yeni başlamış arkadaşlarımız için mesleki gelişime büyük oranda etkisi olur. Yenilenen eğitim programları ve teknikler konusunda aydınlatma olabilir."(Ö3)

Okul müdürlerinin denetiminin mesleki gelişime katkısı olmadığına ilişkin görüş bildiren katılımcılara ait bazı ifadelere aşağıda yer verilmiştir;

"Ders denetiminin yapılması mesleki gelişimime herhangi bir katkı sağlamadı okul müdürünün denetim yapması sınıf yönetimi kanun yönetmelik vb. durumlarda katkı sağlayabilir. Ancak alanımız ile ilgili veya yöntem teknikler ile ilgili bir katkının yapılabilmesi için okul müdürünün de aynı branşa sahip olması veya özel ilgisinin olması gerekir."(Ö5);

"Eksikleri bulma açısından belki katkısı vardır. Ben mesleki gelişime katkısı olduğunu düşünmüyorum. Bu denetimin layıkıyla yapıldığına inanmıyorum. Aslında bu uzmanlık gerektiriyor."(Ö6);

"Okul müdürü çok iyi ders veren öğretmenlerden seçilmiyor ki bana katkısı olsun. Bu konuda müdürler sınıf dışında kalmalı diye düşünüyorum. Öğrencinin rehber öğretmeni olduğu gibi öğretmeninde rehber öğretmeni olmalıdır. Sınıf öğretmeni branş öğretmenin eksik kaldığı yerleri sorması gibi ."(Ö20);

"Mesleki gelişimine bir katkısı yoktur. Sadece görevini yapmak ve öğretmene kontrol edildiği hissini vermek için yapılmaktadır."(Ö18);

"Çoğu idarecinin yeterli donanıma sahip olduğunu düşünmediğim için herhangi bir katkısı olduğunu söyleyemem ."(Ö16);

"Katkı sağlaması mümkün değil zira alan bilgisi ya da mesleki yaklaşım açısından müdürümün nitelikleri yeterli değil. Ancak genel itibariyle insani iletişimine dair sabırlı olmak konusunda rol model olduğunu söyleyebilirim ."(Ö12);

"idareler genelde sonuç odaklıdır. Yaparsınız görürler ve beğenirler, burada üretimin ve yeniliğin temeli öğretmenlerdir. Idareciler yapılanın vitrinidir. Yani bizdeki sistemde yönlendirici yeni açılımlar sunucu öğretmene rehberlik edici bir idare anlayışı yok maalesef ."(Ö10);

"Sadece dersi dinleyip gitmektense bilgi ve tecrübelerinin aktarırsa tavsiyelerde bulunursa verimli olabilir ."(Ö27).

Gül (2007) araştırmasında okul müdürlerinin öğretmenlerin mesleki gelişimlerine katkısına ilişkin orta düzey katkı sağladığı ve özellikle, mesleki gelişme ihtiyaçlarımızı belirleme çalışmaları yapar ve gereken önlemleri alır görüşüne nadiren görüşü belirtmişlerdir.

Genel anlamda mesleki gelişim veya personel geliştirme iş görenlerin mevcut durumdaki ve gelecekteki rollerini en iyi biçimde yerine getirmelerini sağlayacak bilgi, beceri ve tutumlarını doğrudan etkileyen hür türlü etkinliktir. Okul müdürlerinin okuldaki en önemli işlevlerinden biride okul personelinin geliştirilmesinde aktif rol almalarıdır (Robbins ve Alvy, 1995, s.157; akt. Aydın, 2016, s. 220). Okul yöneticisinin iş başında mesleki gelişimi sağlayabileceği etkili enstrümanlardan bir tanesi eğitim denetimidir. Eğitim teftişi, öğretmenlerin mesleki gelişimlerinin teşvik eden onların sorularına çözüm yolları bulmalarına yardımcı olan, eğiten ve değerlendiren, bir süreç olarak değişimin gerçekleştirilebileceği anlayışıdır. Teftiş edilen personelin özel yetenekleri geliştirilmeli ve teşvik edici yollar aranmalıdır; bir kurumda göre yapan personel günlük işler ile uğraşırken çoğu kez kendilerini yoklayamamakta ve 
geliştirilecek yeteneklere sahip olduklarının farkına varamamaktadır. Denetim yapan kişi teftiş esnasında öğretmenin eksik yönlerinin, sahip olduğu özel yetenekleri gözlemeli saptamalı ve geliştirilmesi için yardımcı olmalıdır (Ünal 1989, 449; akt. Taymaz, 2015, 34-91). Bu bağlamda okul yöneticisi örgütün amaçlarını yerine getirebilmesi için en önemli kaynağı olan insan kaynağını geliştirilmesi ve yetiştirilmesini sağlamak durumundadır. Öğretmen görüşlerinde mesleki gelişime yönelik okul idarecilerinden yeterli katkının olmamasına yönelik etkenlerden birinin okul müdürünün böyle bir derdinin olmaması veya eğitimsel denetim mekanizmasını hakkıyla yerine getirecek düzeyde olmamalarından kaynaklandığı söylenebilir.

\section{Denetim sisteminin geliştirilmesine yönelik öneriler}

Katılımcıların yapılan denetim uygulamaların geliştirilmesine yönelik önerileri, Tablo 5'de sunulmuştur.

Tablo 5. Denetim sisteminin geliştirilmesine yönelik görüşler

\begin{tabular}{llcc}
\hline Tema & Öneriler & $\mathbf{f}$ & $\mathbf{\%}$ \\
& & 15 & 50 \\
Denetim Sistemi & -Alanında uzman kişiler olmalı & & 17 \\
& -Öğretmenler yetiştirilerek öz & 5 & 13 \\
& denetimleri geliştirilmeli & 4 & 13 \\
& -Paydaşlar denetlemeli & 4 & 7 \\
\hline
\end{tabular}

Tablo 5' de görüldüğü gibi denetim sisteminin geliştirilmesine ilişkin olarak öğretmenlerin görüşleri; alanında uzman kişiler denetlemeli $(f=15)$, öğretmenlerin iyi yetiştirilerek öz denetimleri geliştirilmeli sağlanmalı ( $f=5)$, paydaşlar denetlemeli $(f=4)$, nitelikli okul müdürleri denetlemeli $(f=4)$, zümre öğretmenleri yer değiştirmeli ( $f=2$ ) yönünde görüş belirtmişlerdir. Denetim sisteminin geliştirilmesine ilişkin görüş bildiren öğretmenlere ait bazı ifadelere aşağıda yer verilmiştir;

"Alanında uzman kişiler tarafından yapılmalıdır. Beni denetleyen birisinin bilgi, beceri, deneyim bakımından benden iyi durumda olmalıdır. Gerekirse üniversitelerde bu konuda yardım alınmalı. Alanında uzman hocalar öğretmenleri denetlemeli adam kayırma ya da torpille gelen bir idareci beni ne kadar denetleyebilir ki."(Ö14);

"Yerinde bir denetim olmasını istiyorsak denetlenecek konunun uzmanı kişiler olmalı. Yeterli donanım ve bilgiye sahip olmalı. Insancıl olmalı. Ben beni denetleyen kişinin Ingilizce öğretmeni olmasını isterim. Benden daha deneyimli ve tecrübeli olsun. Benden daha çok bilgiye sahip olsun isterim. Alanında başarılar elde etmiş bir öğretmen. Ama kesinlikle öğretmen olsun çünkü öğretmenin halinden öğretmen anlar ."(Ö11);

"Denetim özellikle branşında uzman kişilerce yapılırsa iyi olacağını düşünüyorum. Öğretmen rehberlik yaparak ve mesleki gelişimine katkı sağlayacak şekilde olmasını tercih ederim."(Ö18);

"Etkili bir denetimin, denetlediği ya da denetleyeceği alanla ilgili donanıma sahip kişiler tarafından yapılması en sağlıklısı zannımca."(Ö30);

"Küçük okullarda okul müdürü tarafından ders denetimi çok mantıklı ama büyük ve kalabalık okullarda bu çok zor olmaktadır. Uygulama vicdani ve tarafsız yapılırsa tabiki mantıklı ama maalesef burada da ikili ilişkiler ortak yaşam ve paylaşımlar ön plana çıkmaktadır. Ayrıca birçok eğitim kurumunda görev yapan müdürlerin formasyondan ne kadar anladıkları da soru işaretidir. Müdür formasyonla ve iletişimle ilgili bilgi birikimine sahipse verimli olur ama ya değilse ."(Ö1);

"Etkili bir denetimi öğretmenliği hakkıyla yapan öğretmene değer veren öğretmenine güvenen öğretmenine yapıcı eleştirilerde bulunan, idareciler tarafından yapılabilir ."(Ö21);

"Etkili bir denetim; denetim standartlarının önceden belirlendiği ve bildirildiği objektif bakabilen, sadece eksik aramak için değil de rehberlik de yapabilecek kişiler tarafından yapılmalıdır. Denetim materyalleri o branş ya da kuruma özgü olmalıdır. Eğitim deneticisi ya da müfettiş gibi sadece tek kişi tarafından açık arama maksatı değil rehberlik amaçlı olmalıdır. Belki performans değerlendirme sistemi düzenlenerek ilgili idareci, diğer branş öğretmenleri, denetmen gibi birden fazla kişi tarafından yapılabilir. Ayrıca sınıf yönetimi, alan yeterlilikleri, etkili iletişim, planlama, problem çözme becerileri vb. gibi birçok alanda süreç değerlendirmesi şeklinde olması gerektiğini düşünüyorum ."(Ö15); 
"Etkili denetimde birçok faktör bulunmalıdır. Öncelikle denetim süreci sadece bir kişinin özelinde gerçekleşmemelidir. Kontrol mekanizmaları mutlaka olmalıdır. Objektiflik konusunda da okul müdürlerinin değerlendirilmesinin yapılacağı süreçler geliştirilmelidir. Okul müdürlerinin öğretmenlikten gelmiş olmaları büyük bir avantaj gibi gözükse de özellikle farklı branş öğretmenlerinin denetimi esnasında bir çok zorlukla karşılaşacağı aşikardır. Bu zorlukların aşılması açısından özelikle branş derslerde branşında uzmanlaşmış denetim konusunda, tüm eğitimlerini tamamlamış ve geçmişinde belirli süre öğretmenlikte bulunan kişiler tarafından yapılan denetimlerin daha sağıklı olacağını düşünmekteyim. Denetim sonrasında öğretmenin haklarını korumak amacıyla itiraz mekanizmalarının çalıstırılması da ayrı bir önem arz etmektedir. Denetim sürecinin sonunda değerlendirmelere şeffaf şekilde gerçekleştirilmeli varsa öğretmenin eksiklikleri tarafına bildirilmelidir. Tek bir değerlendirme ile öğretmene puanlama yapılmamalı ve denetimlerin tekrarı ile sağlıklı değerlendirmeler yapılmalıdır ."(Ö7);

"Etkili denetim düzenli, süreç ve sonuç odaklı olursa gerçekleşebilir. Beni denetleyecek kişinin kesinlikle alanımla yeterli bilgisi ingilizce öğretmeni yöntem ve tekniklerine hâkim olması, sınıf yönetimi ve öğrenci öğretmen psikolojisine dair bilgisi olması gerektiğini düşünüyorum. Belirli aralıklarla evrakların değil benim denetleneceğimi bilmem mesleki anlamda daha hareketli ve gelişime açık olmamı sağlayacaktır. Türkiye'de şuan denetim süreçlerinin işlememesi benim gibi pek çok öğretmenin kendisini rölantiye almasına sebep oluyor. Kendimize rehberlik yapmak zorundayız ve ne kadar objektif oluyoruz şüpheli, bu şartlar altında öğretmen niteliğinin iyileşmesi beklenemez."(Ö12);

"Denetim hakkı verilerek yapılırsa okul müdür mantıklı geliyor bana. Müdür öğrencilerle de bilgi alışverişi yapmalı bence. Yani öğretmeninizle iletişiminiz nasıl? Akademik durumda derslerin verimli geçip geçmediği hakkında çocuklardan bilgi alınmalı. Ayrıca sadece akademik anlamda da değil kameralardan öğretmenlerin ders giriş-çıkış saatleri de denetlenmeli bence. Çünkü ders zili çalmasına rağmen bazen 10-15 dakika geçmesine rağmen dersine sınıfına girmeyen öğretmenler olmaktadır. Aslında keşke bunlara hiç gerek kalmasa bu peygamber mesleğine kutsallığına yarışır şekilde herkes vicdanen en iyisini yapmak için çalışmalı ama maalesef durum çoğu zaman öyle olmuyor ve denetim zorunlu hale geliyor."(Ö1);

"Kendini geliştiren ve yenilikleri takip eden bir öğretmen vicdan sahibi ve öğrencilerine karşı sabır besleyen bir öğretmenin mesleki gelişsim için denetime ihtiyacı olmayabilir."(Ö22);

"Bence etkili denetim öğretmenin vicdanıdır. Kendi kendini vicdanen denetleyen öğretmenler yetiştirilmelidir ."(Ö23);

"Etkili bir denetim tarafsız bir ekibin habersiz izlemesiyle gerçekleşmelidir. Ya da denetim kalkmalı öğretmenlere daha iyi eğitim verilip denetime gerek kalmamalıdır ."(Ö25)

Bayar (2017), Altun, Şanlı ve Tan (2015), Memduhoğlu ve Taymur (2014) ile illğan (2008)'ın çalışmalarında denetimin bağımsız kişilerce yapılabileceği önerilmiştir. Katılımcıların bazıları okul personelini en iyi tanıyan kişinin okul müdür olduğu için nitelikli okul müdürlerinin öğretmenleri denetlemesi gerektiği, çok az sayıda katılımcı ise zümre öğretmenlerinin yer değiştirerek birbirlerini denetlemeleri yönünde görüş belirtmiş olup araştırma bulgularıyla benzerlik göstermektedir.

\section{Sonuç ve Öneriler}

Araştırmadan elde edilen sonuçlar sırayla incelendiğinde; öğretmenlerin denetim kavramına yönelik görüşlerinin büyük çoğunluğunun denetimi bir kontrol mekanizması olarak gördüğü, bir kısmının belirlenmiş amaçlar ve hedefler doğrultusunda yapılan değerlendirme, gözlem, inceleme, takip, araştırma ve soruşturma durumu şeklinde ifade etmiş olup bir kişide aksaklıkları belirleme ve düzeltme süreci olarak algıladığı sonucuna ulaşılmıştır.

Okul müdürlerinin ders denetimi yeterliliğine yönelik araştırma sonuçlarına bakıldığında öğretmenlerin büyük çoğunluğunun okul müdürünü ders denetimi konusunda yeterli görmemektedir. Yeterli görmeme nedenleri olarak alan bilgisinin eksik olması, branş farklılıklarının olması, bilgi birikimi ve donanım olarak yeterli olmaması, denetimi sadece formalite bir görev olarak yapması, denetimde sadece sınıf yönetimini incelemesi, denetimde yapıcı değil eleştirel bakış açısına sahip olması, derslere girmediği yada çok az girdiği için denetim için yeterliliğe sahip olmadığı gibi sonuçlara ulaşılmıştır. Okul müdürünü denetimde yeterli gören az sayıdaki öğretmen görüşlerine bakıldığında okul müdürüyle rahat fikir alış verişi yaptıkları, okul müdürünün iletişiminin iyi olduğu, hoş görülü ve iyi niyetli olduğu, objektif davrana bildiği, öğretmenleri iyi tanıdığı, aksaklıkları düzeltmeye çalıştığı ve tecrübeli olduğu için denetimde yeterli olduğu sonucuna ulaşılmıştır. Öğretmenlerin okul müdürü denetiminde yaşadıkları olumsuz durumlar olup olmadığına yönelik katılımcıların büyük çoğunluğu olumsuz bir durum yaşamadığını, bir kısmının ise olumsuz durum yaşadığı sonucuna ulaşılmıştır. Olumsuz durumlara örnek olarak ders dinlemek için değil evrak takibi için sınıfa 
gelinmesi, denetimde görülen eksiklikleri sınıf ortamında söylenmesi, habersiz denetim yapılması, denetimle ders akışının bozulması, öğrencilere müdahale edilmesi, müdürün öğretmene üstünlük kurma çabası, denetim durumunun derste öğrencilerde tedirginlik oluşturmasını belirtmişlerdir.

Okul müdürlerinin denetiminin öğretmenlerin mesleki gelişimine etkisine yönelik sonuçlar incelendiğinde katılımcıların büyük çoğunluğu okul müdürlerinin denetiminin mesleki gelişimlerine anlamlı bir katkı sağlamadığını, çok az kısmı ise mesleki gelişimlerine olumlu etkisi olduğunu belirtmişlerdir. Katkı sağlamadığına yönelik görüş bildiren öğretmenlerin buna sebep olarak branşlarının farklı olması, okul idarecilerinin iyi bir öğretmen olarak görmemeleri, denetim anlayışlarının sadece belge kontrolü olduğu, denetim için yeterli donanıma ve bilgi birikimine sahip olunmaması, denetimin sadece kontrol edilme hissi vermesi görüşlerini belirtmişlerdir. Mesleki gelişime katkısı olduğunu dile getiren katılımcılar ise okul müdürlerinin denetimle en çok göreve yeni başlayan öğretmenlere tecrübelerini aktararak fayda sağladığı, öğretmenlik uygulamalarıyla ilgili yardımı olduğu ve teşvik edici üslup kullanmasının mesleki gelişime katkısı olduğunu dile getirmişlerdir.

Denetim sisteminin geliştirilmesine yönelik katılımcı görüşlerine bakıldığında öğretmenlerin büyük çoğunluğunun denetim gerçekleştirilecekse bunun alanında uzman kişiler tarafından yapılması gerektiğini, bir kısmı denetimin dışarıdan sürekli yapılmasının çokta etkili olmayacağını öğretmenlerin iyi yetiştirilerek görev bilinci vicdanına sahip, öz denetimlerini yapabilmesinin sağlanması gerektiğini dile getirmiştir. Katılımcıların bir kaçı tek kişinin bu okul müdür veya müfettiş olsun yeterli ve objektif olmayacağı paydaşlar tarafından denetimin gerçekleşmesi gerektiğini dile getirmişlerdir.

Bu çalışmadan elde edilen sonuçlar doğrultusunda aşağıdaki öneriler getirilmiştir;

1-Denetim kavramının öğretmenlerce stres kaynağı değil, yapıcı ve geliştirici etkiye sahip bir yönetim süreci olduğu bilincinin eğitimlerle verilmeye çalışılması, ayrıca denetimde mesleki rehberliğe ağırlık verilerek hata arayıcı değil hata azaltıcı bir süreç izlenmeli,

2- Kanun ve yönetmeliklerle birçok görev ve sorumluluk verilen okul idarecilerinin seçiminde çok hassas davranılması, sadece bürokratik işlerle uğraşan sorun istemeyen değil, öğretmenlere eğitim ve öğretim alanında iyi bir lider ve örnek olacak kişilerin seçilmesi için yönetim alanında lisansüstü eğitim yapmış kişilerin objektif kriterlere göre seçim yapılarak atanması,

3- Okul yöneticilerine alanında uzman kişiler tarafında denetim ve rehberlik alanında eğitimler verilmesi,

4- Denetim sisteminin sürece dayalı olması, okul idarecisi alanında uzman bir denetçi, zümre öğretmenleri vb. paydaşlarında sürece dâhil edildiği öğrenci başarısının da dikkate alındığı bir sistemin geliştirilmesi,

5- Eğitim fakültelerinde uygulanacak ders ve etkinlikler ile öz denetim becerisi gelişmiş ve işini severek yapan öğretmenler yetiştirilmesinin üzerinde durulması gerekmektedir.

\section{Kaynakça}

Altıntaş, R. (1992). Illköğretimin teftişi. Hacettepe Üniversitesi Eğitim Fakültesi.

Altun, M., Şanlı, Ö. ve Tan, Ç. (2015). Maarif müfettişlerin, okul müdürlerinin denetmenlik görevleri hakkındaki görüşlerinin incelenmesi.

TurkishStudies,10(3),7996.http://www.turkishstudies.net/DergiTamDetay.aspx?ID=7913\&Detay=Ozet sayfasından erişilmiştir.

Aydın, i.(2016). Öğretimde denetim (6.baskı). Ankara: Pegem Akademi.

Aydın, M. (2014). Çağdaş eğitim denetimi (6.baskı). Ankara: Gazi Kitapevi.

Bayar, T. (2017). Maarif Müfettişlerinin Sınıflarda Uyguladığı Rehberlik ve Denetim Uygulamalarının Kaldırılmasına ilişskin Öğretmen Okul Müdür ve Maarif Müfettişlerinin Görüşleri. Yayımlanmamış Yüksek Lisans Tezi, Mehmet Akif Ersoy Üniversitesi Eğitim Bilimler Enstitüsü, Burdur.

Bige, E. F.(2014). Illkokul Müdürlerinin Ders Denetimleri ile Ilgili Öğretmen Görüşleri. Yayımlanmamış Yüksek Lisans Tezi, Adnan Menderes Üniversitesi Sosyal Bilimler Enstitüsü, Aydın.

Dağ, A. (2016). Okul Yöneticilerinin Ders Denetimi Yapmalarına ilişkin Öğretmen Algıları. (Denizli ili Acıpayam ilçe Örneği). Yayımlanmamış Yüksek Lisans Tezi, Pamukkale Üniversitesi Eğitim Bilimler Enstitüsü, Denizli. 
Demir, M. (2009). Ilköğretim Müfettişlerinin Ders Teftişlerinin Öğretmenler Tarafından Değerlendirilmesi. Yayımlanmamış Yüksek Lisans Tezi, Yeditepe Üniversitesi Sosyal Bilimler Enstitüsü, İstanbul.

Ergen, H., Eşiyok, i. (2017).Okul müdürlerinin ders denetimi yapmasına ilişkin öğretmen görüşleri. Çağdaş Yönetim Bilimleri Dergisi, 3(1), 2-19.

Gül, K. (2007). Okul Yöneticilerinin Öğretmenlerin Mesleki Gelişimlerine Katkılarının Belirlenmesi. Yayımlanmamış Yüksek Lisans Tezi, Yeditepe Üniversitesi Sosyal Bilimler Enstitüsü, İstanbul.

Illğan, A. (2008). İlköğretim müfettişleri ve öğretmenlerinin farklılaştırılmış denetim modelini benimseme ve uygulanabilir bulma düzeyleri. Kuram ve Uygulamada Eğitim Yönetimi, 55, 389422.http://dergipark.ulakbim.gov.tr/kuey/article/view/5000050614 sayfasından erişilmiştir.

Karasar, N. (2012). Bilimsel araştırma yöntemi (Yirmi üçüncü baskı). Ankara: Nobel Yayıncılık.

Köybaşı, F., Uğurlu C.T., Bakır, A.A. ve Karakuş, B. (2017). Illkokullarda ders denetimine ilişkin öğretmen görüşleri. Turkish Studies International Periodical for the Languages, Literature and History of Turkish or Turkic Volume 12/4, p. 327-344.

MEB. (2000). 2508 sayılı Tebliğler dergisi: Okul müdürünün görev, yetki ve sorumluluğu. MEB: Ankara.

Memduhoğlu, H., B. ve Taymur A. (2014). Türkiye'de eğitim denetimi alt sisteminin yeniden yapılandırılmasına ilişkin bir model önerisi. Pegem Eğitim ve Öğretim Dergisi, 4,(2), 25- 44.

Miles, M, B.,\& Huberman, A. M. (1994). Qualitative data analysis: An expanded source book. (2nd ed). Thousand Oaks, CA: Sage.

Özer, B. (2008). Öğretmenlerin mesleki gelişimi(A.Hakan Ed.). Öğretmen meslek bilgisi alanındaki gelişmeler, s.195216. Eskişehir Anadolu Üniversitesi Açık öğretim Fakültesi.

Özmen, F. (2000). Klinik denetim öngörüleri çerçevesinde denetçi görüşleri. Fırat Üniversitesi Sosyal Bilimler Dergisi. 10(1), 119-157.

Şahin, T. (2005).ilköğretim Düzeyinde Ders Denetimiyle ilgili Yeterlilikler Hakkında Denetmen ve Öğretmen Görüşleri. Yayımlanmamış Yüksek Lisans Tezi, Abant İzzet Baysal Üniversitesi Sosyal Bilimler Enstitüsü, Bolu.

Taymaz, H. (2015). Teftiş; kavramlar, ilkeler, yöntemler (11. Baskı).Ankara: Pegem Akademi.

Tonbul, Y., ve Baysülen, E., (2017). Ders denetimi ile ilgili yönetmelik değişikliğin maarif müfettişlerinin, okul yöneticilerinin ve öğretmenlerin görüşleri açısından değerlendirilmesi. Ilköğretim Online, 16(1), 299-311, 2017

Yeşil, D. (2018). Okul Müdürlerinin Ders Denetimine ilişkin Öğretmen Görüşleri. Yayımlanmamış Yüksek Lisans Tezi, Inönü Üniversitesi Eğitim Bilimler Enstitüsü, Malatya.

Yıldırım, A. ve Şimşek H. (2005). Sosyal bilimlerde nitel araştırma yöntemleri. Ankara: Seçkin Yayıncılık

Yıldırım, A. ve Şimşek H. (2011). Sosyal bilimlerde nitel araştırma yöntemleri. Ankara: Seçkin Yayıncılık. 